\title{
Experience in the Region to Increase the Availability of Housing Services
}

\author{
Anna llyinichna Romanova \\ Gulsina Mansurovna Zagidullina \\ Albina Nazipovna Afanasyeva \\ Regina Sergeevna Hkairetdinova
}

Kazan State University of Architecture and Engineering, Russian Federation, Republic Tatarstan, 420043, Kazan, Zelenaya str., 1

\section{Doi:10.5901/mjss.2015.v6n4s2p549}

\section{Abstract}

This article will review the policy aimed at creating a favorable investment climate for housing development in the region in order to meet the housing needs of its citizens. The mechanism of credit state support housing through the use of "property" of lending, which gives a real boost to housing affordability without a mortgage, housing and storage and other financial mechanisms.

Keywords: housing services, housing policy, construction, housing affordability, state support mechanism

\section{Introduction}

\subsection{Problem setting.}

The need for state support for the development and functioning of the housing is characterized by the importance of social values and is an area of livelihood of citizens, that is a factor that contributes to the national security. In the regulation of housing can not be guided only by the principles of market economy, as between these principles and social policies, there are considerable differences. In all developed countries, the housing sector is regulated by the state, both at the national and at the local level, both directly and indirectly. In this context, it becomes obvious that no reasonable mechanism of state support interaction between participants of housing construction, the housing problem will be amplified because there is an increase of social tension associated with the increase in prices for housing, tax charges and fees for the maintenance and operation of housing.

\subsection{Latest research and publications analysis.}

Regulatory issues and housing administration considered in O.E. Bessonova (Bessonova, 2011), G.M. Zagidullina, A.I. Romanova (Romanova et al., 2013; Zagidullina et al., 2013; Zagidullina et al., 2013), Bagautdinova N.G. (Safiullin et al., 2012) and many others (Bakri et al., 2012; Sadeghi and Bozorgnia, 1994; Box and Jenkins, 1970; Cho, 2014). Problems of reforming and housing development in the regions and municipalities investigated in Fengguang Jiang (Jiang, 2012), A.N. Asaul (Asaul and Batrac, 2001), Ying Xie (Xie, 2011), Rumaizah Mohd Nordin (Rumaizah et al., 2012) and others (Khasanov, 2014). At the same time, in the conditions of modern realities strategy development and implementation of regional housing policy is still in the early stages of its development and does not have the support, based on an understanding of the population of the importance of this strategy for the improvement of living standards (Yashin et al., 2015; Assanova, 2015).

\subsection{The research objective}

The research objective is to analyze the development and implementation of socio-economic foundations of housing strategy to improve housing affordability in the region with the participation of the population in financing the construction. 


\section{Method}

The methodological basis of the research were the methods and principles of systems-based approach, the functionalstructural modeling, logical analysis, statistical, program-targeted methods.

The empirical base of the research were legislative and regulatory acts of the Russian Federation and the Republic of Tatarstan, the official statistics, analysis of the Ministry of Construction, Architecture and Housing and Communal Services of the Republic of Tatarstan, the Ministry of Economy of the Republic of Tatarstan.

Scientific research is based on the modeling of real-life situations with the action of different state laws and the consequences of their use. For simplicity and brevity consideration of a complex set of laws of their direct and immediate impact on the availability of housing allocated only by the example of the implementation of the program of housing policy and accounting nature of the distribution of income citizens of Tatarstan.

The theoretical basis of scientific studies provided the scientific works of domestic and foreign scholars in the field of theory and practice of formation and regulation of the housing stock, the formation of industrial organization, state and municipal government, the socialization of the system of relations in the economy, as well as monographs and publication in the official press on the researched topic.

\section{Results}

Social and affordable housing for citizens determined by the value of property and income. However, if you go into the concept of "affordable housing" in more detail, we can say that housing affordability is defined more purchasing power in the housing market. In this case, it should be considered that part of the income of the population (savings), which is directed to the acquisition of property. From this perspective, all the approaches to the problem of increasing the availability of housing due to the introduction of state mechanisms can be divided into two areas: reducing the cost of housing and increase the purchasing power of the population for housing.

Program policy for solving the housing problems in the Republic of Tatarstan allows for the creation of an integrated system of mortgage lending (Krivtsov, Kalimullin, 2015), which includes the provision of housing to citizens in installments and credit mechanism of state support for housing construction through the use of "property" of lending.

Initially for program policy development of housing construction in the Republic of Tatarstan and state support for citizens was necessary to solve complex economic and organizational and management (legal) problems:

1) the problem of creating and managing public investors, who will have to carry out housing construction by the state (republic) funds with the subsequent transfer of housing and home ownership in the property owners;

2) the problem of creating and reserving land fund, which should be determined prior to the capitalization of Housing and transfer the property in the future citizens who are homeowners;

\subsection{The first group of problems}

The decision of the first group of problems is to develop the principle of state support, implemented in the Republic of Tatarstan, with the possibility of repayment of the loan granted to them by citizens. Such a possibility is established, firstly, a rule for calculating the duration of the loan period - "n" years, and, secondly, the rule allocation social stratum in the Republic of Tatarstan, capable to purchase a house in the property. In the latter case, usually highlight the social strata of citizens determined by the difference values of per capita income of citizens and the minimum consumer budget.

State support of the citizens, tied to the state regulation of housing provision. This condition is associated with limited public resources. As part of the housing policy implemented in the Republic of Tatarstan, the following regulations such provision:

- thirty-three square meters - one resident citizen;

- forty-two square meters - for family numbering two people;

- sixteen square meters per person - for a family of four or more number of people.

State support to the provision of premises, exceeding the norm of housing provision for fixed discounted price should be $20 \%$.

The principle of social and economic access to housing is the housing policy of the Republic of Tatarstan, mainly, but not only. Thus, taking into account the real incomes of all citizens, divided into different social groups (Ajupov et al., 2015). Each group has its own set quota determined by the proportion of the number of apartments to be built.

The first layer of citizens to form a waiting list of municipal economy. They form a social stratum of citizens who are in need of urgent support. For this category of citizens formed a separate quota. 
The second layer is formed by citizens who work in state and municipal institutions (public sector workers). The main reasons for the formation of such categories are: low salaries (in this case, the government and municipal authorities are responsible for the stability of income); in relation to this category can be used long-term loans, as their labor contracts and conditions of work are long-term or indefinite character. Thus, for a set of social categories of benefits.

Next quota is characterized by the formation of necessary and appropriate, as connected with the creation of sources of financing housing. It is the means of enterprises, which are sent to the construction. Accordingly, for the workers of these enterprises receiving credit support, formed a separate quota.

Citizens who receive federal government's financial support of the program "Young family", "Soldiers", form the last social group. For these categories set their quotas, taking into account the amount of money received from the federal budget.

In general, established in the Republic of Tatarstan system such differentiation state support and competition in the "quota" can be considered a success.

\subsection{The main idea of state support for housing construction}

Thus, given the above criteria, will present the main idea of state support used in the Republic of Tatarstan - giving citizens a property loan. Under the leadership of the state of a single owner-developer (public housing) at the expense of public resources to build housing that is available to citizens, selected in the competition and sign a contract with the state of the housing stock. In the role of the customer's building stands created building society where citizens come wishing to participate in the construction of housing. Builder in this case performs the function of purely contractors. The Parties shall cooperate on the basis of the construction contract, which makes it possible to avoid all the problems arising from the use of "gray" schemes. Cooperative, speaking on behalf of the customer and in the interests of its members, shareholders: approves design documentation, coordinates all changes to it in the course of construction; monitors the performance of contractual obligations by the construction organization; controls the order and amount of development of financial and other resources; reviews and approves questions appreciation of construction; conducts technical supervision, quality control of construction and installation work; involved in the acceptance of new housing in operation.

Under current law cooperatives have the right to form a variety of funds, including credit and make loans and loans to its members, without a banking license under the terms of mutual assistance. This makes it possible to use these funds for the purposes of crediting of citizens participating in the cooperative framework of the new, lower barrier housing affordability for the majority of the population and better address the issues of affordable housing. Citizens entering into a cooperative, making $50 \%$ of the market value of the property (the initial payment during the period of construction of a residential building, according to a fixed schedule of payments), and get a new home with the installments for the balance of debt for up to 27 years on favorable terms (low interest rate, the possibility of reducing the down payment, the possibility of "amnesty" in the case of disability). The value of the initial contribution to be paid in the process of building a house should be installed so that it covers the actual cost of construction, and provide return on investment within 1-2 years. All other amounts received by installment payments are net income on invested capital, and can be directed to the reinvestment of life (Romanova et al., 2013).

This mechanism allows you to reach more in need of better living conditions and more effectively implement the basic ideas of the priority national project "Affordable and comfortable housing for Russian Federation". Furthermore, it allows:

- exclude financial intermediaries in the face of banks;

- exclude burden of citizens, the values of which can reach $50 \%$ or more of the market value of property;

- exclude the appearance of collateral housing prices.

The application of this mechanism helps to reduce the cost of purchased housing doubled compared to housing, which is acquired through a mortgage.

The most important benefit for the citizens of the state support is that if a citizen is not able to purchase the entire housing and to fulfill its obligations under the contract, he receives a refund most of the money and loses the right to tenure.

In the case of mortgage loans, the citizen loses not only home ownership, but the funds that have been paid on account of repayment of the loan, as well as the right to payment of insurance compensation in case of loss of health.

Thus, government support citizens in the Republic of Tatarstan has a number of important advantages than other mechanisms to improve housing affordability.

Principle payments on property lending mechanism for an apartment built in such a way that its annual growth 
offset by higher average per capita income (for example, the growth of per capita income in 2014 increased relative to 2013 by $9.5 \%$ (The territorial body of the Federal State Statistics,1999)). In addition, it was noted that loan repayment is proportional share repurchased property, expressed in square meters. Thus, there is a decrease in the cost of rental housing due to the decrease of the unredeemed property. For example, the area of housing for rent is $50 \%$ of the actual living space, provided that paid $50 \%$ of the property loan, expressed in monetary terms.

\subsection{The second group of problems}

The decision of the second group of problems is innovative (Sadyrtdinov et al., 2015). The problem to solve was due to the fact that under the Land Code of the Russian Federation land for construction of houses to be sold to developers on a competitive basis.

Using the rules of the Land Code of the Russian Federation, according to which the authorities of the federal subjects have the right to develop and implement targeted social programs within the concept provided for the establishment of the first in Russia "Fund land reserve" and the relevant government agency of the Government of the Republic of Tatarstan (Figure 1). Decree of the President of the Republic of Tatarstan on the establishment of such a fund was issued in January 2003 (Romanova et al., 2013).

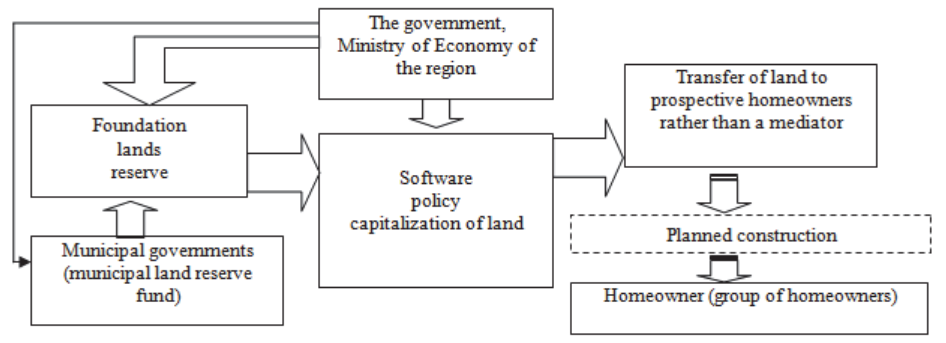

Figure 1. Scheme of formation of fund-aside land in the region

Purpose of the Fund reserve land:

- the accumulation of land from the land of the Republic of Tatarstan and land settlements (in coordination with local authorities);

- capitalization reserve land for the development of engineering and transport infrastructure necessary for the design and planning of housing construction in accordance with targeted social programs;

- the transfer of land reserve in a free limited use for the construction of housing for people - future owners in need of government support.

Thus, the exclusion mechanism sale and resale of land to reduce the cost of housing.

The planning and implementation of a single zone capitalization of land needed for future urban planning and bind future apartment buildings to a single social engineering and transport infrastructure. The use of such capitalization reduces the cost of housing and the protection of such costs by the subsequent inflation. Earth derived from the reserve, are not subject to property tax.

In general, this approach of housing policy of the Republic of Tatarstan, can be considered successful.

\section{Discussion}

Thus, in view of the above we can formulate the conclusion that all efforts at the federal level measures (through targeted programs aimed at certain categories of citizens) can not fully solve the problem of providing citizens with affordable housing. The main reason is the rapid increase in the value of residential properties in comparison with the growth of real household incomes, high housing affordability barrier for the vast majority of the population. The situation is aggravated by the fact that there is no single concept of effective regulation of housing construction and housing and communal services at the regional and municipal level. This leads to a decrease in effective demand and the overall stagnation in the real estate market.

The proposed strategy to address the housing problem in the Republic of Tatarstan includes organizational and economic mechanism of state support for citizens in home ownership, which allows you to increase the availability of 
housing. In particular, this concept provides:

Firstly, the proposed economic mechanism of credit support, which lowers the barrier housing affordability due to:

- use of the mechanism of internal lending member housing co-operative without the use of collateral, thus eliminating the additional cost burdens and the threat of losing their homes;

- use of a system of prior savings for construction purposes;

- application of the system of targeted support for certain categories of the population due to increase in terms of installments and reduction of initial contributions;

- formation before the housing perspective form of government residential house - building society;

- reducing construction costs for citizens participating in the program.

Secondly, the formation of organizational-administrative mechanism, which includes the activities of all the subjects and the real estate market determines the shape of their interaction as members of a single process that will:

- effectively accumulate funds for housing finance, build and transfer home ownership;

- ensure repayment of budget investments in social housing, due to the formation of economic circulation of capital in the region, the country, region;

- use the mechanism of reinvestment.

Third, the establishment of an effective mechanism of state support for the organizers of housing using contract granting tariff preferences, which in turn will allow the organs of state (regional and municipal) authorities to introduce a market mechanism medium- and long-term planning of capital turnover and rights, the conditions of capitalization of land revenue funds in the budget and extra-budgetary funds.

Fourth, the creation of a "Fund land reserve" that allows both to reduce the cost of housing at the expense of the free provision of land for construction, as well as mechanisms to eliminate the sale and resale of land. This will ensure that the planning and implementation of a single zone capitalization of land necessary conditions for future urban planning and bind future apartment buildings to a single social engineering and transport infrastructure. The use of this capitalization will reduce the cost of housing.

\section{Conclusion}

In conclusion, it should be noted that within the framework of the study, namely in the solution of the second group of problems it is necessary to solve the problems of the third group, the essence of which is as follows. Future homeowners should:

- to group whose members are to buy housing in the future home;

- to group whose members are to consolidate their savings allocated for the implementation of construction and repayment of debts in the process of foreclosure of property;

- to group whose members will be in the future participants of common ownership to all general real estate in the house and in the household.

There was a problem creating a specialized legal entity that is under its control will solve these problems.

Already under construction apartment houses and savings mobilization of citizens for the purpose of such construction is necessary to create a specialized legal entity that will serve as the owner under construction, and then built, the apartment building. However, the study of this group of problems in a scientific article, unfortunately, failed to hold. And of course, this direction will be the subject of future study researches.

\section{References}

Ajupov, A.A., Kurilova, A.A. \& Ivanov, D.U. (2015). Hedging as an Important Component of the Financial Mechanism of Enterprise Management in the Automotive Cycles (Vol. 6, pp. 45-49). Mediterranean Journal of Social Sciences. DOI: 10.5901/mjss. 2015.v6n1s3p45

Asaul, A.N. \& Batrac, A.V. (2001). Corporate structures in regional investment and construction complex. Moscow: DIA.

Assanova, M.A. (2015). Public Policy \& Model of Sustainable Development in the Republic of Kazakhstan. Asian Social Science, Vol 11, 6, 237-244. DOI: 10,5539 / ass.v11n6p237

Bakri, A.K., Wong, S.L., Zulkefly, A.K. \& Jais, M. (2012). The Impact of Subprime Mortgage Crisis on Islamic Banking and Islamic Stock Market. Procedia. Social and Behavioral Sciences, Volume 65, 3, 668-673

Bessonova, O.E. (2011). Housing razdatok and modernization of Russia. Moscow: Publishing House "Russian Political Encyclopedia (ROSSPEN)".

Box, G.E.P. \& Jenkins, G.M. (1970). Time-series Analysis: Forecasting and Control. San Francisco: Holden-Day. 
Cho, I. (2014). Homeownership and Investment in Risky Assets in Europe. Review of European Studies, Vol 6, 4, 254-268. DOI: 10.5539/res.v6n4p254

Jiang, F. (2012). The Study of the Relationship between House Price and Price Tolerance in China from the Perspective of Systems Engineering. Systems Engineering Procedia, Volume 5, 74-80.

Khasanov, I.Sh. (2014). Three-Sector Structure of the National Economy of Russia. Asian Social Science, Vol 10, 20, 217-225. DOI: 10.5539/ass.v10n20p217

Krivtsov, A.I., Kalimullin, D.M. (2015). The Model of Changes Management Information System Construction. Review of European Studies, Vol 7, 2, 10-14. DOI: 10.5539/res.v7n2p10

Romanova, A.I., Lantsov, V.M. \& Afanasyeva, A.N. (2013). National security: availability of housing rights from the perspective of citizens of Russia to motherhood and childhood. Publisying House FINANCE and CREDIT, 42, 63-68.

Rumaizah, M.N., Roshana, T., \& Abdul, H.N. (2012). Transparency Initiatives (TI) in Construction: The Social Psychology of Human Behaviours/ Procedia. Social and Behavioral Sciences, Volume 50, 350-360.

Sadeghi, H. \& Bozorgnia, A. (1994). Moving average and complete convergence. Bull. Iranian Math. Soc, 20, 37-42.

Sadyrtdinov, R.R., Korablev, M.M and Vladimirova, S.A. (2015). Regional Innovation System Development: Comparative Analysis of the Republic of Tatarstan and Volga Federal District Regions. Mediterranean Journal of Social Sciences, Vol 6, 1, 317-321. DOI: 10,5901 / mjss.2015.v6n1s3p317

Safiullin, L.N., Bagautdinova, N.G., Safiullin, N.Z. \& Gafurov, I.R. (2012). Influence of quality of the goods on satisfactions of consumers. International GSTF Business Review (GBR), Vol 2, 2, 225-232.

The territorial body of the Federal State Statistics (1999). Retrieved February 12, 2015, from http://tatstat.gks.ru.

Xie, Y. (2011). Research on the Land Scale Control Model of Public Housing Construction in China: An Example of Harbin. Procedia Engineering, Volume 15, 5121-5125.

Yashin, N.S., Andreeva, T.A., Serebrjakov, A.V. \& Bagautdinova, N.G. (2015). Implementation of the Strategy: Problems and Solutions. Mediterranean Journal of Social Sciences, Vol 6, 1, 475-481. DOI: 10.5901/mjss.2015.v6n1s3p475

Zagidullina, G.M., Romanova, A.I. \& others (2013). Indicative Model of Socio-Economic Development of Small Towns. World Applied Sciences Journal: IDOSI Publications, 24, 350-357. DOI: 10.5829/idosi.wasj.2013.24.03.13203.

Zagidullina, G.M., Romanova, A.I. \& others (2013). Peculiarities of Housing Construction Development in the Region. Middle-East Journal of Scientific Research, 16, 490-495. 